\section{九州ーパラオ海蘢上のギョー}

$$
\text { 茂木昭夫·加俊雄 }
$$

1960 年 8 月, 観測船拓洋で潮岬南南西 325 浬 の駒橋海山を調查した際，その南方 11 浬の地 点に海山（拓洋海山）を発見し、ギョーである ことを知った。

フィリッピン海盆は, パラオ海領に続く九州パラオ海嶺によって2 分される(Fig. 1)。この海 額にも火山脈の存在が期待される11。調査結果 (Fig. 2)によれば，水深約 $4000 \mathrm{~m}$ の海盆底から 䄪 $2000 \mathrm{~m}$ の楥隆起带 (海膨) かi 北北西〜南南 東に走り，海山はこの海膨上に更に約 $1500 \mathrm{~m}$ 琴立する。海膨は東に楥かに凸面を向け，その

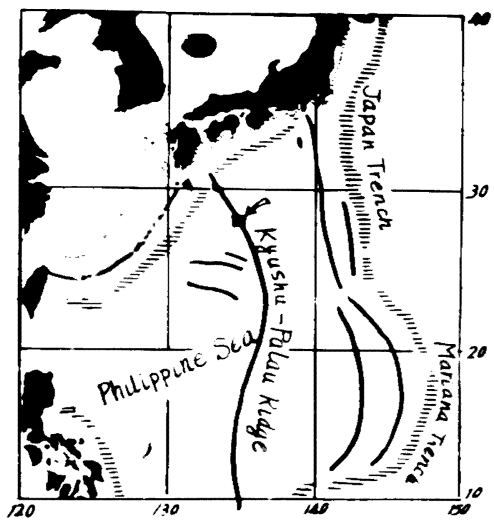

Fig. I Index map of Kyushu-Palau Ridge

東斜面は西斜面より倾斜大で音呮記録こは表面 に数百米の起伏がある。1940年軍㩜駒橋が発 見した駒橋海山は，最小水深 $500 \mathrm{~m} ・$ : 形で，頂部は丸味をおび平頂ではない。

拓洋海山は, 山頂の深さは $700 \mathrm{~m}$ で平頂であ る。この平頂面は, 地質資料を久くが, 波蝕面 と思われ，この深さで海水準が忩满したことを 示す。西太平洋の若干の礁上六ーリンフの結 果 ${ }^{2)}$ によると, 著しく離れた地域において礁

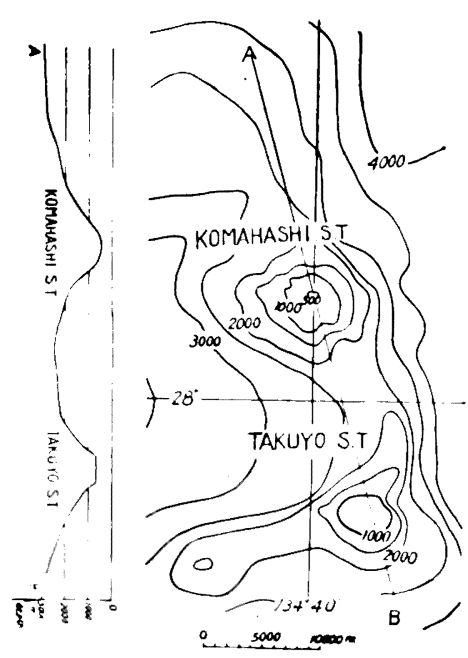

Fig. 2 Bathymetric chart and profile of Komahashi and Takuyo Seamounts

性石兏岩の示す旧海水準に大きな深さの差がな いから，この地域においても，礁性石灰岩に示 された海面の上昇過程が成り立つとすると，約 $700 \mathrm{~m}$ の 平坦面の示す旧海準は漸新世頃とな る。

駒橋・拓洋両海山は，地形からみて，おそら く海瞦上に噴出した火山であろう。水深が大き い拓洋海山が切頭され，より浅い駒橋海山が切 頭されていないのは，次のように考えられる。 濑新世頃に海膨上に海底火山が形成され，現在 より約 700m 低かった当時の海面上に現われた 火山はその頂部が波蝕により切頭された。その 後の海面上昇によりこの海山は海中に没した が(拓洋海山)， その北方 11 浬に発生した噴火 による駒橋海山は, 海面上に出なかったため, 原形を保って今日に至った。

1）茂木清夫(1961)：地震の起り方一破壊論の立場 加5 地球科学 73 28 31

2) Shepard, F.P. (1963): Submarine Geology 2nd ed.

\title{
A Guyot on the Northern Part of Kyushu-Palau Ridge
}

\section{Akio MOGI and Toshio KATO}

Two seamounts on the northern part of Kyushu-Palau Ridge were explored by the Takuyo Expedition in August 1960. These seamounts stand abruptly about $1500 \mathrm{~m}$ above a swell rising about $2000 \mathrm{~m}$ gently from the Philippine Sea Basin with a NNWSSE direction.

One of them, the Komahashi Seamount appears to have an uneven top which has its peak at the depth of $500 \mathrm{~m}$. The peak of the other seamount, the Takuyo guyot, is conical with a distinctly flat top 3.7 kilometers wide. There is a distinct break in the slope around the Takuyo guyot at the depth of about 700 meters. Apparently this seamount is a wave-truncated submerged volcano like the guyots on the Mid-Pacific-Mountains. 